
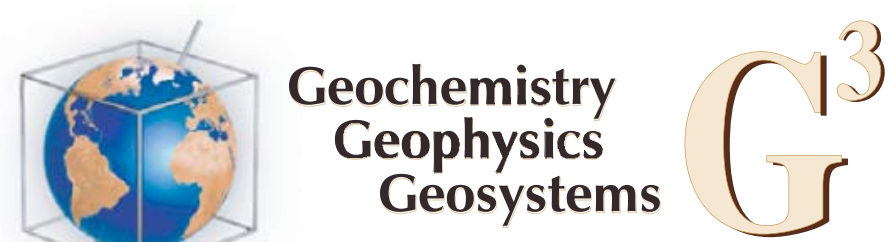

\title{
Crustal structure across the Costa Rican Volcanic Arc
}

\author{
Jorden L. Hayes and W. Steven Holbrook \\ Department of Geology and Geophysics, University of Wyoming, Laramie, Wyoming 82071, USA \\ (jhayes18@uwyo.edu)
}

\section{Dan Lizarralde}

Department of Geology and Geophysics, Woods Hole Oceanographic Institution, Woods Hole, Massachusetts, USA

\section{Harm J. A. Avendonk}

Jackson School of Geosciences, University of Texas Institute for Geophysics, Austin, Texas, USA

\section{Andrew D. Bullock}

WesternGeco Ltd, Scblumberger House, Gatwick Airport, UK

\section{Mauricio Mora and Carlos Ramírez}

Escuela Centroamericana de Geología, University of Costa Rica, San Pedro, Costa Rica

\section{Steven Harder}

Department of Geological Sciences, University of Texas at El Paso, El Paso, Texas, USA

\author{
Guillermo E. Alvarado \\ Escuela Centroamericana de Geologia, University of Costa Rica, San Pedro, Costa Rica \\ Instituto Costarricense de Electricidad San José, Costa Rica
}

[1] Island arcs are proposed to be essential building blocks for the crustal growth of continents; however, island arcs and continents are fundamentally different in bulk composition: mafic and felsic, respectively. The substrate upon which arcs are built (oceanic crust versus large igneous province) may have a strong influence on crustal genesis. We present results from an across-arc wide-angle seismic survey of the Costa Rican volcanic front which test the hypothesis that juvenile continental crust is actively forming at this location. Travel-time tomography constrains velocities in the upper arc to a depth of $\sim 15 \mathrm{~km}$ where average velocities are $<6.5 \mathrm{~km} / \mathrm{s}$. The upper $5 \mathrm{~km}$ of crust is constrained by velocities between 4.0 and $5.5 \mathrm{~km} / \mathrm{s}$, which likely represent sediments, volcaniclastics, flows, and small intrusions. Between 5 and $15 \mathrm{~km}$ depth, velocities increase slowly from 5.5 to $6.5 \mathrm{~km} / \mathrm{s}$. Crustal thickness and lower crustal velocities are roughly constrained by reflections from an inferred crust-mantle transition zone. Crustal thickness beneath the volcanic front in Costa Rica is $\sim 40 \mathrm{~km}$ with best-fit average lower-crustal velocities between 6.8 and $7.1 \mathrm{~km} / \mathrm{s}$. Overall, velocities across the arc in central Costa Rica are at the high-velocity extreme of bulk continental crust velocities and are lower than modern island arc velocities, suggesting that continental compositions are created at this location. These data suggest that preexisting thick crust of the Caribbean Large Igneous Province has a measurable effect on bulk composition. This thickened arc crust may be a density filter for mafic material and thereby support differentiation toward continental compositions.

Components: 10,500 words, 9 figures, 1 table. 
Keywords: continental crust; island arc; seismic refraction; Costa Rica.

Index Terms: 8102 Tectonophysics: Composition of the oceanic crust; 8185 Tectonophysics: Volcanic arcs.

Received 11 October 2012; Revised 31 January 2013; Accepted 31 January 2013. Published 29 April 2013

Hayes, J. L., W. S. Holbrook, D. Lizarralde, H. J. A. van Avendonk, A. D. Bullock, M. Mora, S. Harder, G. E. Alvarado, and C. Ramírez (2013), Crustal structure across the Costa Rican Volcanic Arc, Geochem. Geophys. Geosyst., 14, 1087-1103, doi:10.1002/ggge.20079.

\section{Introduction}

[2] Island arcs are the surface representation of interaction between mantle-wedge flux melting and the overlying material within intraoceanic subduction zones and have been postulated to be a source of post-Archean building material for continental crust [Anderson, 1982; Kay and Kay, 1991; Rudnick, 1995]. Primary evidence for island arcs as continental building blocks comes from trace-element signatures of continental crust which are most similar to those found at convergent margins and less like those found at mid-ocean ridges and ocean islands [Taylor and McLennan, 1985; Christensen and Mooney, 1995; Rudnick and Gao, 2003]. This leads to a compelling contradiction, designated the "andesite paradox" [Taylor and McLennan, 1981], since island arcs primarily produce mafic melts such as basalts [e.g., Kay and Kay, 1986; Smithson et al., 1981], whereas continental crust is approximately intermediate (i.e., andesitic) in bulk composition [Christensen and Mooney, 1995; Rudnick and Fountain, 1995; Rudnick, 1995]. If island arcs are a significant contributor to continental crustal volume, there must be a process for modifying basaltic arc melt into andesitic continental crust. Various mechanisms have been proposed, including fractionation and/or anatexis [e.g., Behn and Kelemen, 2006; Kelemen, 1995], delamination of mafic and ultramafic residuals [e.g., Ducea and Saleeby, 1998], sediment relamination [Hacker et al., 2011], modification by accretion [e.g., Draut et al., 2009], or some combination thereof. Crustal structure and composition inferred from seismic velocities can further clarify the relative roles of these processes in the genesis of continental crust.

[3] Previous seismological studies of active island arcs reveal a range of arc composition from dominantly mafic (e.g., the Aleutian arc [Holbrook et al., 1999; Schillington et al., 2004]) to large heterogeneous regions containing some intermediate material (i.e., the Izu-Bonin arc [Suyehiro et al., 1996; Takahashi et al., 2008; Calvert et al., 2008]).
Despite these variations, average arc crust has a dominantly mafic composition in all intraoceanic arcs studied to date [Calvert, 2011]. While each arc is unique in the combination of variables that drive lava chemistry, a few specific variables help explain compositional variance and the evolution of island arc material to more continental-like compositions. For example, the Izu-Bonin arc, which contains areas of intermediate material, has seen a relatively large amount of extension compared to the Aleutian arc, which has little extension and is dominantly mafic [Calvert, 2011]. Volcano-scale variations of seismic velocity along the Izu-Bonin arc have been attributed to differing stages of continental growth [Kodaira et al., 2007]. Other factors that influence arc compositions include composition and hydration of the subducting slab [e.g., Patino et al., 2000], convergence rate [e.g., Kelemen et al., 2003; Hughes and Mahood, 2008], and the composition, structure, and thickness of the overriding plate.

[4] The substrate upon which intraoceanic arcs are built (i.e., oceanic crust versus large igneous province) may have a significant influence on material differentiation and thereby continental genesis [Albarède, 1998; Vogel et al., 2004, 2006]. The volcanic front in central Costa Rica is a prime location to study subduction-related magmatic crust because it is built upon a preexisting large igneous province that provides a thicker initial crust to the arc-building process. The relative importance of this substrate can be seen in the emplacement of upper-crustal silicic magmas over the Caribbean Large Igneous Province (CLIP) [Vogel et al., 2004, 2006]. Vogel et al. [2004] proposed that silicic products in the upper and middle crust of Costa Rica were derived from anatexis and/or fractional crystallization of stalled magmas. Thus, the CLIP may potentially act as a density filter and thereby have a strong influence on arc composition in Costa Rica.

[5] In order to test the role of the CLIP in the formation of the volcanic arc in Costa Rica, two 
active-source seismic surveys were conducted in 2005 and 2008 as a part of project TICO-CAVA. In this paper, we present tomography results from the 2005 across-arc transect (Figure 1). Our seismic velocity model closely constrains velocities in the upper $15 \mathrm{~km}$ of crust; velocities in the lower crust (15-40 km depth) are roughly constrained by deep crustal and upper mantle reflections, which are interpreted to coincide with a crust-mantle transition zone (CMTZ).

\section{Tectonic and Geologic Setting}

[6] Arc volcanism along the western edge of the Caribbean Plate has been ongoing since at least $65 \mathrm{Ma}$ with early subduction of the Farallon Plate [Giunta et al., 2006]. The modern Central Volcanic Cordillera in Costa Rica has been forming since the Eocene-Oligocene from shallow subduction of the Cocos Plate beneath the Caribbean Plate [Meschede and Frisch, 1998]. At present, the Cocos and Caribbean Plates are converging along the Middle America Trench (MAT) at a rate between 8 and $9 \mathrm{~cm} / \mathrm{yr}$ [DeMets, 2001].

[7] The Cocos Plate is $\sim 24 \mathrm{Ma}$ at the MAT [Barckhausen et al., 2001] and displays distinct morphological features that have been correlated with regional geochemical and isotopic variations in arc volcanism [Carr, 1984; Carr et al., 1990; von Huene et al., 2000; Patino et al., 2000; Abers et al., 2003; Hoernle et al., 2008; Gazel et al., 2009]. In particular, the Cocos Plate has a region of rough seafloor associated with interactions between the Cocos-Nazca spreading center and the Galapagos hot spot, a region of smooth seafloor from the East Pacific Rise spreading center, and a large ridge (the Cocos Ridge) created by volcanism at the Galapagos hot spot [von Huene et al., 1995]. Geochemical trends along the arc, specifically contributions from a hydrous serpentinized slab mantle source beneath Nicaragua [Abers et al., 2003; Eiler et al., 2005] and a basaltic source beneath Costa Rica [Hoernle et al., 2008], correlate with deep flexural faulting parallel to seafloor fabric at the outer rise near Nicaragua and less deeply faulted lithosphere near Costa Rica [Rüpke et al., 2002; Ranero et al., 2001].

[8] The volcanic arc in Costa Rica is built upon two major tectonic blocks, the Chortis Block and the Chorotega Block [Dengo, 1985]. The Chortis Block is primarily underlain by Paleozoic continental basement [Rogers et al., 2007], and the Chorotega Block is underlain by $\sim 20 \mathrm{~km}$ of CLIP crust [Sinton et al., 1998] that formed during Late Cretaceous hot spot volcanism [Hauff et al., 2000; Meschede and Frisch, 1998, and references therein]. The boundary between these two terranes is debated within a $\sim 100 \mathrm{~km}$ range between southern Nicaragua and northern Costa Rica [Dengo, 1985; Hauff et al., 2000; MacKenzie et al., 2008; Baumgartner et al.,

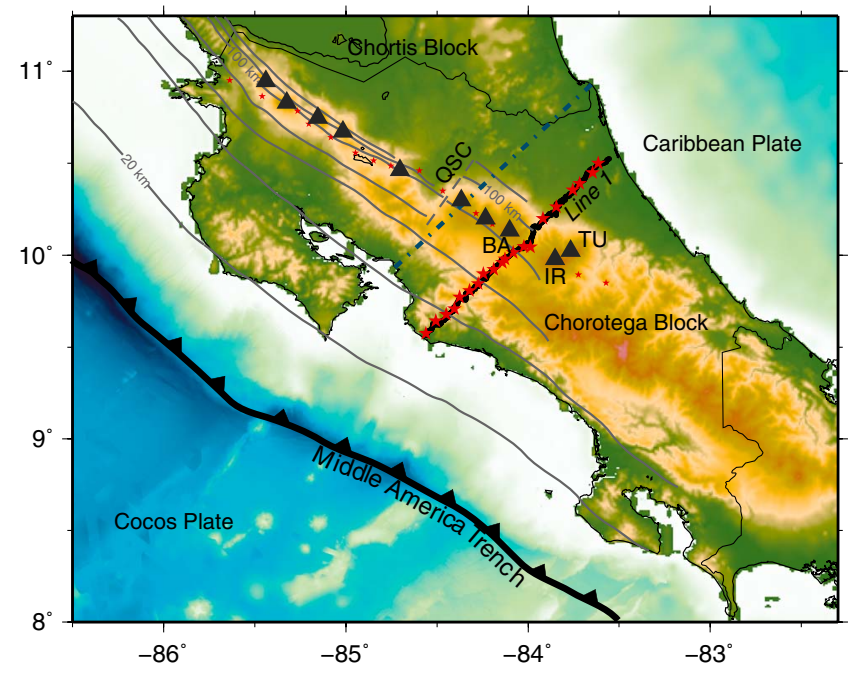

Figure 1. Location map of the Central American Volcanic Arc with pertinent tectonic features. Slab depth contours (gray) are shown with a contour interval of $20 \mathrm{~km}$ (QSC: Quesada Sharp Contortion) [Protti et al., 1994]. Locations of active volcanoes are denoted with black triangles (BA: Barva, TU: Turrialba, IR: Irazu). The southernmost debated boundary between the Chortis and Chorotega blocks is shown by the blue dashed line [Linkimer et al., 2009]. Stars indicate shot locations - larger stars denote the profiles presented in this paper; smaller stars indicate the along-arc transect also collected in this survey. Black circles are receiver locations. 
2008; Linkimer et al., 2009]. Our profile lies south of the southernmost proposed boundary for the Chorotega Block, and thus the arc here is likely to have been built upon the CLIP (Figure 1).

[9] Magmatism in central and northern Costa Rica has been producing extensive silicic ignimbrites from $\sim 6$ Ma to present [Vogel et al., 2004]. Throughout deposition of these silicic lavas, overlapping volcanic ranges were produced by northeastern arc migration from the Cordillera de Aguacate to the modern Central Volcanic Cordillera [Marshall et al., 2003]. Vogel et al., 2004, 2006 propose that emplacement of subduction-related silicic magmas is transforming the CLIP in Costa Rica to continental crust. The proposed mechanism for evolving silicic magmas (i.e., juvenile continental crust) in Costa Rica relies upon partial melting or fractional crystallization of recently emplaced, mantle-derived, hot, stalled magmas [Vogel et al., 2004, 2006].

[10] Previous geophysical studies of the northern and central Costa Rican volcanic arc have suggested compositions similar to continental crust but have limited resolution in defining crustal boundaries and velocity gradients [e.g., McIntosh et al., 1995, 2000; Sallarés et al., 1999, 2000, 2001; Husen et al., 2003; Linkimer et al., 2009; MacKenzie et al., 2008]. These studies agree upon a relatively thick $(30-40 \mathrm{~km})$ crust with lower crustal velocities less than $7.5 \mathrm{~km} / \mathrm{s}$. The upper plate has been divided into three layers based on velocity gradients: a layer of extrusive volcanics in the upper crust, a layer of basalts related to the CLIP, and a layer of mafic granulites that transition to a low-velocity mantle containing underplated basaltic magmas [Sallarès et al., 2001].

\section{Seismic Data Acquisition and Processing}

[11] In 2005, we conducted a wide-angle seismic refraction experiment across the Costa Rican segment of the Central American Volcanic Arc. Here we present results from the $154 \mathrm{~km}$-long across-arc transect. Twenty explosive sources were detonated at an average $7 \mathrm{~km}$ spacing, although source spacing is denser on the southwest half of the line $(\sim 5 \mathrm{~km}$ interval). Seismic sources ranged from 300 to $1025 \mathrm{~kg}$ of pentaerythritol tetranitrate explosives in drill holes up to $60 \mathrm{~m}$ beneath the ground surface. Larger sources were placed at the end of the profile to increase the signal-to-noise ratio at far-offset receivers. Seismic data was recorded using 742 vertical-component short-period Reftek seismometers from the U.S. national seismic instrumentation facility IRIS/PASSCAL with a $200 \mathrm{~m}$ receiver interval and $4 \mathrm{~ms}$ sample rate. Minimal processing was required to interpret shot gathers and involved a 5-10 Hz minimum-phase bandpass filter and velocity reduction of $6 \mathrm{~km} / \mathrm{s}$. Overall, data quality is good with a high signal-to-noise ratio on most shot gathers (Figure 2, auxiliary material). Crustal refractions are observed at most offsets, and reflections are observed on several gathers, especially at the longest offsets. Travel-time picks of first arrivals and secondary arrivals were made by hand using the filtered and reduced record sections. Picks were made on data with velocity reduction of $6 \mathrm{~km} / \mathrm{s}$ to assist in distinguishing between upper and lower crustal arrivals. The 20 shot gathers provided a total of 9971 travel-time picks for crustal turning compressional waves $(\mathrm{Pg})$ and 584 travel-time picks of reflected arrivals.

\section{Methods}

\subsection{First Arrival Tomography}

[12] Seismic travel times from crustal refractions were used to constrain the upper-crustal velocity structure across the Costa Rican Arc. Travel-time picking errors were calculated to increase with offset and range from $50 \mathrm{~ms}$ at well-resolved nearoffsets to $150 \mathrm{~ms}$ at the farthest offsets where noise has the largest affect on interpretation. Using the first-arriving energy from each of the 20 explosion sources, we inverted for a 2-D velocity model using Tomo2D [Korenaga et al., 2000]. This method employs a hybrid ray-tracing method that combines the graph and ray bending methods. The model was parameterized as a mesh hanging beneath the land surface with node spacing every $300 \mathrm{~m}$ laterally and $50 \mathrm{~m}$ vertically. The initial velocity model used a 1-D velocity-depth function hung from the model topography. We subsequently conducted iterative ray-tracing and linearized inversions to converge to a well-fitting seismic velocity model. To regularize the inversion, we applied correlation lengths that increase linearly with depth and range from 5 to $10 \mathrm{~km}$ horizontally and 1 to $5 \mathrm{~km}$ vertically. As stopping criteria for the iterative inversion, we minimized the root-mean-square (RMS) traveltime residuals such that the RMS does not vary more than $10 \mathrm{~ms}$ between two successive iterations. After five iterations, the misfit was sufficiently reduced to an RMS of $64 \mathrm{~ms}$, and the chi-squared statistic $\left(\chi^{2}\right)$ was reduced to 0.71 . The final velocity model for the upper $20 \mathrm{~km}$ of crust is shown in Figure 3. 

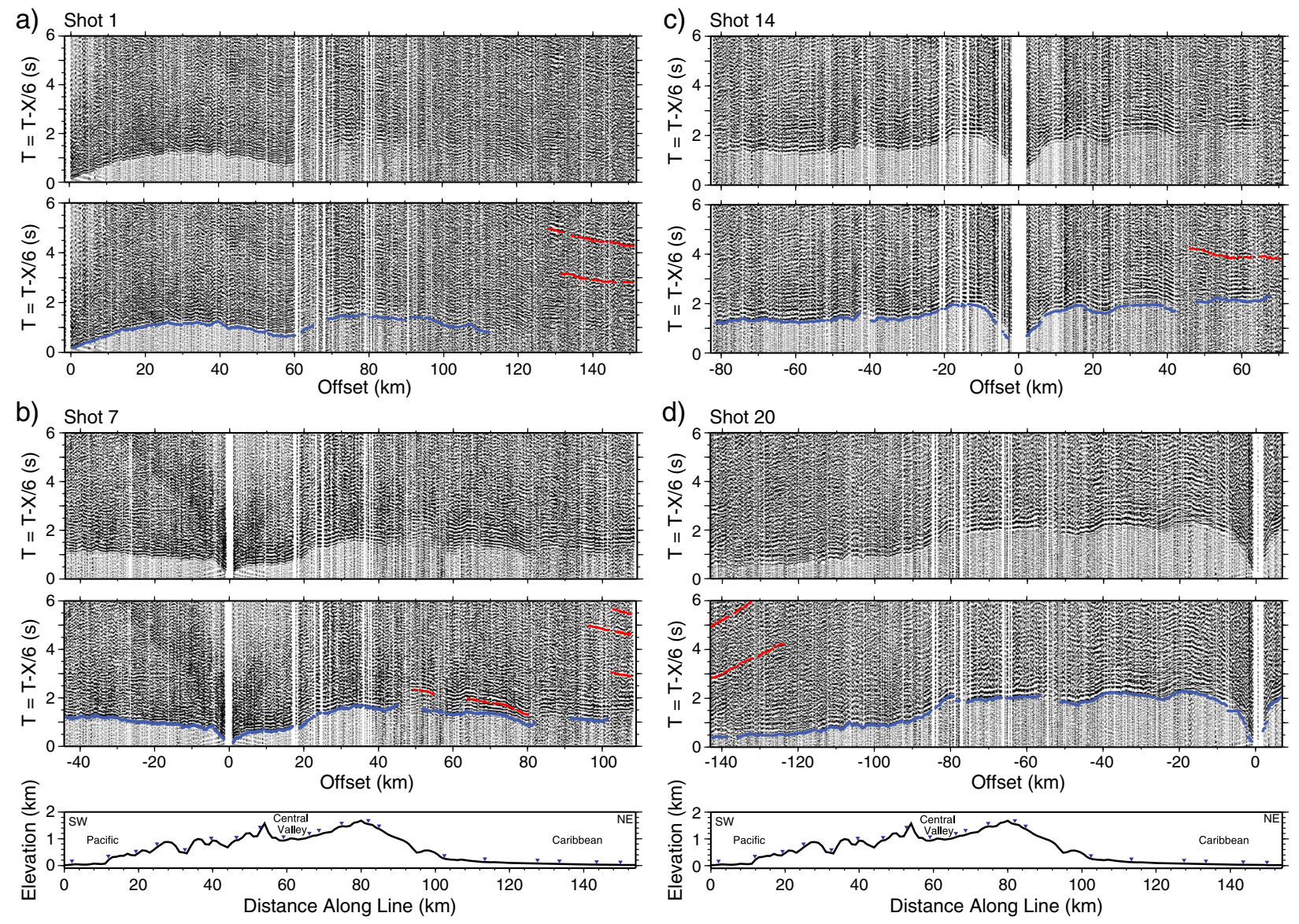

Figure 2. Examples of shot gathers collected across the Central American Volcanic Arc in Costa Rica: (a) Shot 1, (b) Shot 8, (c) Shot 16, and (d) Shot 24. All recorded phases are shown (top) with a reduction velocity of $6 \mathrm{~km} / \mathrm{s}$. Picked first arrivals (blue) and reflected phases (red) are displayed (bottom). The horizontal axis is source-receiver offset. Data are displayed with a $5-10 \mathrm{~Hz}$ minimum-phase bandpass filter. Vertically exaggerated elevation profiles with shot locations (blue triangles) are displayed beneath shot gather pairs.

\subsection{Floating Reflectors}

[13] To maximize the utility of this data set and avoid a priori bias by defining boundaries given a limited number of observations and small survey aperture, we modeled reflections observed in the shot gathers as floating reflectors using the ray-tracing code RAYINVR [Zelt and Smith, 1992; Zelt and Forsyth, 1994]. Limited reciprocity among few reflections on the shot gathers make identifying consistent reflective boundaries difficult. Floating reflectors allow reflective interfaces to be modeled as segments that "float" within the velocity model without assigning a particular velocity structure. To estimate mid-lower crustal velocities, we independently modeled twenty floating reflectors by subjecting each reflector to individual velocity models that vary in average mid-lower crustal velocity. Each reflector was then plotted by color according to its best-fit averagevelocity model (Figure 4 ).
[14] During the modeling process, we found many different statistically acceptable models for a given floating reflector because of the velocity-depth ambiguity common to seismic modeling, and also assigned picking errors allow for a range of apparent velocities. The inversion process can inadequately represent apparent velocities of travel-time arrivals due to picking error allowance, which enables the model to overcompensate travel-time picks at the beginning and end of a reflection, thus driving RMS misfit toward an acceptable but misleading value. Therefore, we employed an additional statistical approach to further constrain velocities in the midlower crust. We chose a best-fit velocity model that minimizes the mismatch between the apparent velocities of the observed arrivals (i.e., picked arrivals) and synthetic arrivals (i.e., arrivals calculated from ray-tracing) [Smith, 1999]. Apparent velocities were calculated as the slope of the observed and synthetic arrivals. For a given average-velocity model to 


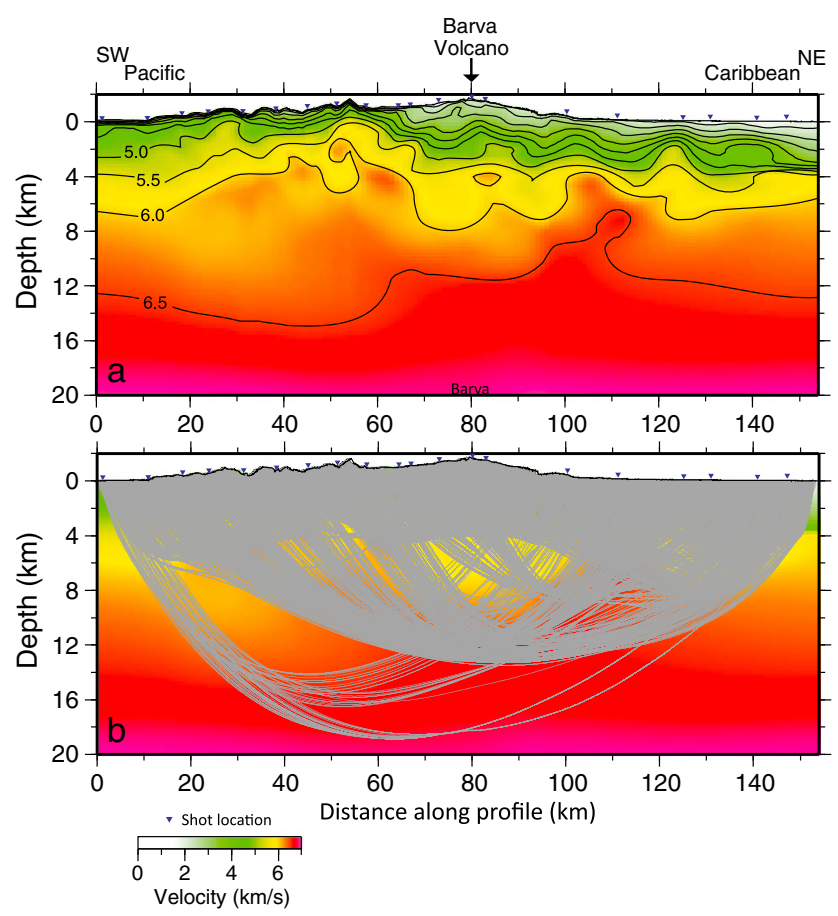

Figure 3. (a) Travel-time tomography velocity model from wide-angle data for the across-arc transect. Blue triangles represent the position of explosive sources. Picks from all 20 shot gathers were used in the model. In general, green represents low $(<5 \mathrm{~km} / \mathrm{s})$ velocities, and higher velocities $(>6 \mathrm{~km} / \mathrm{s})$ are red. The surface location of the modern arc (Barva Volcano) is denoted by an arrow. (b) Ray coverage overlaid on the final velocity model from travel-time tomography. Ray coverage is densest in the upper $5 \mathrm{~km}$ but sufficient to constrain velocities below the modern arc to $\sim 15 \mathrm{~km}$ depth.

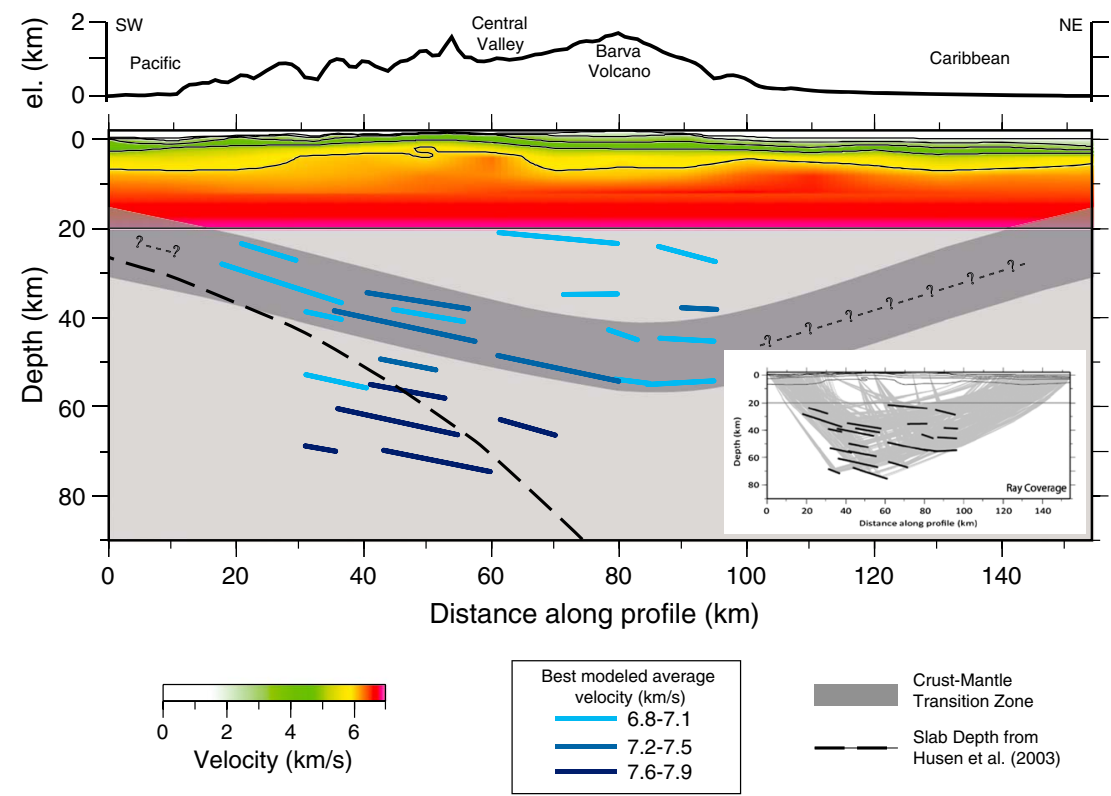

Figure 4. Modeled floating reflectors (blue lines) displayed with their respective best individually modeled average velocities $(6.8-7.1 \mathrm{~km} / \mathrm{s}$, light blue; $7.2-7.5 \mathrm{~km} / \mathrm{s}$, blue; $7.6-7.9 \mathrm{~km} / \mathrm{s}$, dark blue). The accepted velocity model for the upper- and mid-crust from earlier travel-time tomography is displayed to $20 \mathrm{~km}$ depth. Slab depth from Husen et al. [2003] is shown by a black dashed line. The interpreted crust-mantle transition zone is highlighted in dark gray with question marks in areas with little or no ray coverage. Ray coverage is shown in the bottom right corner inset. 
fit the travel-time observations acceptably well, it must minimize the RMS travel-time residual as well as match the observed apparent velocity within $\pm 0.5 \mathrm{~km} / \mathrm{s}$. Each reflector was modeled in separate velocity models by incrementing the average velocity in the mid-lower crustal layer $(20-70 \mathrm{~km}$ depth) by $0.1 \mathrm{~km} / \mathrm{s}$ from 6.8 to $7.8 \mathrm{~km} / \mathrm{s}$ while maintaining the first-arrival tomography model to $20 \mathrm{~km}$ depth. In each velocity model, the reflector depth and geometry (i.e., dip) parameters were updated by inversion. The criterion to choose the best-fit reflector within each velocity model was to minimize the RMS travel-time residual and the apparent velocity mismatch while still tracing $90 \%$ of the observed travel times. For a given arrival, the best-fit statistics for the modeled reflectors from every velocity model were plotted, and the model that minimized the RMS and slope mismatch was chosen as the best average-velocity model for that arrival observation (Figure 5). Table 1 provides an estimate of the trade-off between velocity and reflector geometry for two representative reflectors. From the compiled statistics (e.g., Table 1) and previously defined criterion, we estimate error for velocity is $\pm 0.3 \mathrm{~km} / \mathrm{s}$, depth of reflector is $\pm 5 \mathrm{~km}$, and dip of the reflector $\pm 3^{\circ}$. In all cases, the RMS values either supported the best-fit choice based on the slope mismatch calculation or were not minimized, and the slope mismatch alone provided a good criterion for defining a range of average velocities for which a reflector was best modeled.

[15] The statistically best-fitting floating reflectors along with ray coverage are shown in Figure 4. Due to vertical and lateral heterogeneities as well as a lack of refracted rays at these depths, we show each reflector color-coded by the best-fit average velocity. Most reflectors have a slight dip toward the northeast as required by the models to account for the high apparent velocities of the travel-time picks. In general, the mid-lower crust below the arc in Costa Rica is highly reflective with lower average velocities $(6.8-7.5 \mathrm{~km} / \mathrm{s})$ modeled for reflectors $<50 \mathrm{~km}$ depth. These velocities are similar to preliminary results reported by a coincident doublesided onshore-offshore survey [Everson et al., 2012]. The highest average-velocity reflectors are located at depths similar to slab depths obtained by Husen et al. [2003].

\section{Results}

\subsection{Seismic Velocity Model}

[16] Our final model contains velocities of $5.0-6.6 \mathrm{~km} / \mathrm{s}$ in the upper crust to a depth of $15 \mathrm{~km}, 6.6-7.5 \mathrm{~km} / \mathrm{s}$ a)

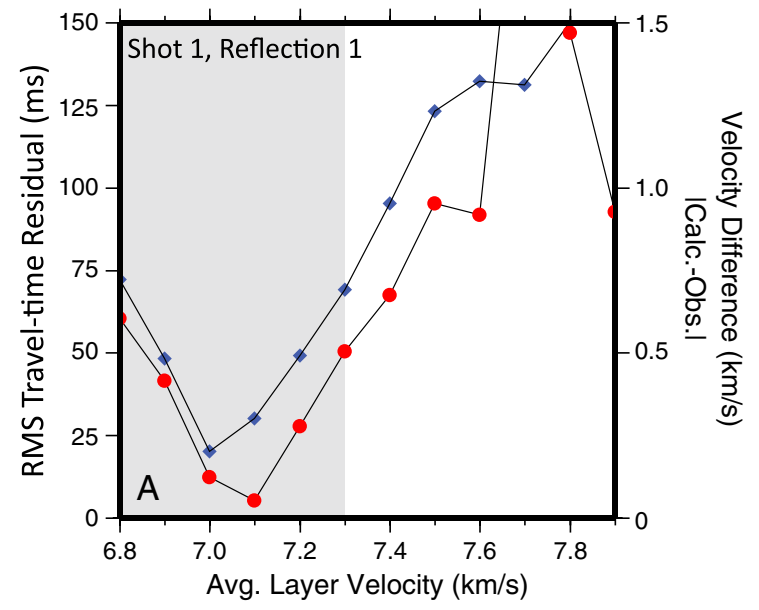

b)

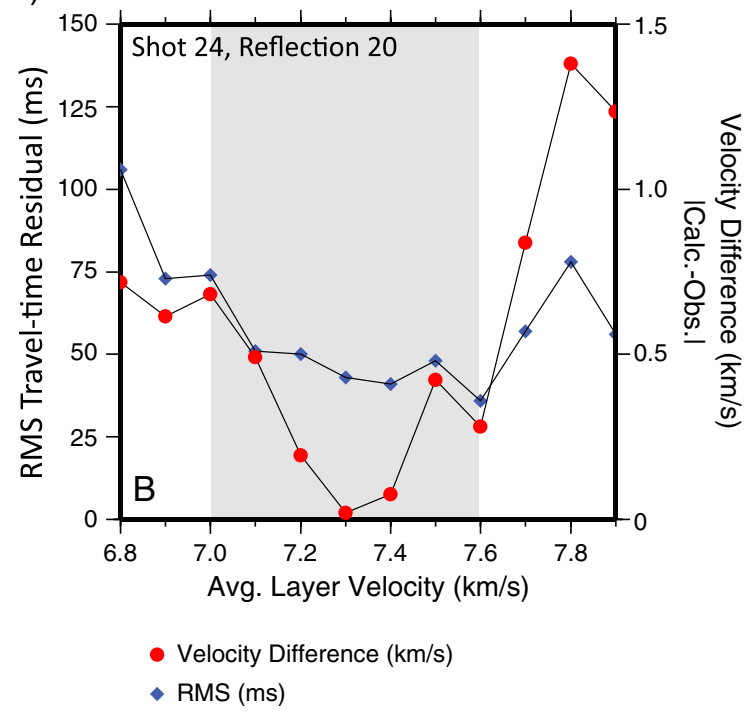

Figure 5. Statistics plots used to determine best-fit average layer velocity for each floating reflector: RMS travel-time residual (blue diamonds) and difference between calculated and observed apparent velocities (red circles). (a) Statistics from reflection 1 trend together and make the best-fit modeled velocity easy to identify. (b) Statistics from reflection 24 do not trend together, and the velocity difference calculation is used to identify the best-fit modeled velocity. Gray areas indicate a region of acceptable velocities used to estimate error.

in the middle and lower crust, and a total crustal thickness beneath the active arc of $40-50 \mathrm{~km}$ (Figures 3 and 4). The primary features observed in the upper-crustal model (Figure 3) are a high-velocity anomaly beneath Barva Volcano ( $\mathrm{km} 80$ in the model) and elevated velocities under the Cordillera de Aguacate ( $\mathrm{km} 50$ in the model) and the extinct Sarapiquí Arc ( $\mathrm{km} 110$ in the model). Features of the floating reflector model include a region of reflectors with similar dip and low average velocities 
Table 1. Modeling Statistics from Representative Floating Reflectors ${ }^{\mathrm{a}}$

\begin{tabular}{|c|c|c|c|c|c|c|c|}
\hline $\begin{array}{l}\text { Average } \\
\text { Velocity }^{\mathrm{b}}\end{array}$ & $\begin{array}{l}\mathrm{RMS} \\
(\mathrm{ms})\end{array}$ & $\chi^{2}$ & $\begin{array}{l}\text { \# Rays } \\
\text { Traced }^{\mathrm{c}}\end{array}$ & $\begin{array}{c}\text { Velocity } \\
\text { Difference }^{\mathrm{d}}(\mathrm{km} / \mathrm{s})\end{array}$ & $\begin{array}{l}\text { Average Depth to } \\
\text { Reflector }(\mathrm{km})\end{array}$ & $\begin{array}{c}\text { Reflector } \\
\text { Length }(\mathrm{km})\end{array}$ & $\begin{array}{l}\text { Reflector } \\
\operatorname{Dip}^{\mathrm{e}}(\mathrm{deg})\end{array}$ \\
\hline \multicolumn{8}{|c|}{ Shot 1 , Reflection 1 (22 travel-time observations) } \\
\hline 6.8 & 72 & 0.543 & 22 & 0.60 & 46.5 & 6.6 & -21.0 \\
\hline 6.9 & 48 & 0.239 & 22 & 0.41 & 49.7 & 6.3 & -18.8 \\
\hline 7.0 & 20 & 0.044 & 22 & 0.12 & 52.4 & 7.5 & -15.7 \\
\hline 7.1 & 30 & 0.093 & 21 & 0.05 & 54.8 & 7.3 & -16.0 \\
\hline 7.2 & 49 & 0.253 & 19 & 0.28 & 56.8 & 7.2 & -16.4 \\
\hline 7.3 & 69 & 0.503 & 19 & 0.50 & 58.7 & 7.1 & -13.8 \\
\hline 7.4 & 95 & 0.941 & 22 & 0.67 & 60.2 & 7.9 & -14.9 \\
\hline 7.5 & 123 & 1.594 & 19 & 0.95 & 61.9 & 8.2 & -14.3 \\
\hline 7.6 & 132 & 1.826 & 18 & 0.92 & 63.4 & 8.5 & -16.2 \\
\hline 7.7 & 131 & 1.801 & 19 & 2.20 & 64.8 & 8.0 & -17.3 \\
\hline 7.8 & 150 & 2.394 & 14 & 1.47 & 66.1 & 7.8 & -17.7 \\
\hline 7.9 & 162 & 2.820 & 14 & 0.93 & 67.5 & 7.8 & -17.7 \\
\hline \multicolumn{8}{|c|}{ Shot 24 , Reflection 20 (25 travel-time observations) } \\
\hline 6.8 & 106 & 1.233 & 14 & 0.72 & 34.7 & 3.9 & -25.4 \\
\hline 6.9 & 73 & 0.580 & 18 & 0.62 & 35.8 & 9.0 & -21.8 \\
\hline 7.0 & 74 & 0.612 & 13 & 0.68 & 36.9 & 9.2 & -21.1 \\
\hline 7.1 & 51 & 0.275 & 23 & 0.49 & 39.0 & 7.2 & -20.4 \\
\hline 7.2 & 50 & 0.269 & 18 & 0.20 & 40.8 & 7.9 & -20.4 \\
\hline 7.3 & 43 & 0.193 & 23 & 0.02 & 41.6 & 15.2 & -19.2 \\
\hline 7.4 & 41 & 0.177 & 18 & 0.08 & 44.3 & 8.2 & -19.7 \\
\hline 7.5 & 48 & 0.246 & 23 & 0.42 & 46.1 & 15.2 & -15.9 \\
\hline 7.6 & 36 & 0.141 & 17 & 0.28 & 48.0 & 12.9 & -16.2 \\
\hline 7.7 & 57 & 0.344 & 20 & 0.84 & 49.0 & 13.1 & -17.2 \\
\hline 7.8 & 78 & 0.648 & 24 & 1.38 & 51.9 & 11.9 & -12.1 \\
\hline 7.9 & 56 & 0.330 & 22 & 1.24 & 53.2 & 10.5 & -11.0 \\
\hline
\end{tabular}

${ }^{a}$ Italicized values represent estimated range of acceptable values based on reported statistics.

${ }^{\mathrm{b}}$ Average velocity of the lowermost layer in which all reflectors are modeled.

${ }^{c}$ Or the number of travel-time observations modeled.

${ }^{\mathrm{d}}$ See section 4.2 for a description of the velocity difference calculation.

${ }^{\mathrm{e}}$ Most reflectors in this study dip to the NE.

highlighted in Figure 4 as a crust-mantle transition zone and a region of reflectors with high average velocities that have a similar depth to the subducted slab that has been modeled in other studies (e.g., Husen et al., 2003).

\subsection{Resolution and Uncertainty Analysis}

[17] The overall data misfit observed in the model will be affected by errors in travel-time picks, the subjectivity of travel-time phase interpretation, projection of the 3-D experiment geometry onto the 2-D modeled profile, and accuracy of the initial velocity model chosen for inversion. First-arrival refractions have assigned picking errors that range from $50 \mathrm{~ms}$ at near-offsets to $150 \mathrm{~ms}$ at offsets where first arrivals are apparent but difficult to identify precisely. Deep crustal reflections have assigned errors of $100 \mathrm{~ms}$. Pn and PmP phases are not strictly interpreted in this data set due to a limited maximum offset; therefore, the subjectivity of phase interpretation is greatly reduced. Firstarrival refractions with an uncertain travel time, caused by acquisition effects and local effects such as absorption or attenuation, have a large picking error and were excluded from the inversion. Due to the 3-D distribution of sources and receivers along our profile, we projected these locations onto a 2-D line. This projection will introduce some distortion via shortened ray paths because offset is not preserved. Average offline projection is $\sim 500 \mathrm{~m}$, which gives a projected error of $\sim 80 \mathrm{~m}$ at $1.5 \mathrm{~km}$ offset and an estimated uncertainty of $\sim 40 \mathrm{~ms}$ at a velocity of $2 \mathrm{~km} / \mathrm{s}$. The near-offset error is dominated by this distortion, whereas the far-offset error is dominated by picking uncertainty; thus, we assign a picking error of $50 \mathrm{~ms}$ for near-offset arrivals.

[18] To quantify uncertainty and model convergence in our final model, we conducted a Monte Carlo simulation, and, to test structural resolution, we inverted synthetic travel times created from checkerboard-style velocity models. A first-order assessment of model resolution can be made through observations of the total ray coverage (Figure $3 \mathrm{~b}$ ). Dense ray coverage is observed in the upper $5 \mathrm{~km}$ across the entire model and up to $15 \mathrm{~km}$ beneath 
the active arc, giving confidence that these areas are well resolved. The modeling of floating reflectors, discussed later, places additional constraints on model structure.

[19] A Monte Carlo simulation was performed to estimate the variability of $P$-wave velocities within acceptable models given our interpreted travel-time picks [Tarantola, 1987; Korenaga et al., 2000]. We produced 343 starting models from 1-D velocitydepth profiles that vary in gradient and span the range of velocities shown in Figure $6 \mathrm{~b}$. We generated starting velocity-depth profiles for the Monte Carlo simulation by perturbing the average-velocity-depth profile of our initial model by $\pm 0.6 \mathrm{~km} / \mathrm{s}$, in increments of $0.3 \mathrm{~km} / \mathrm{s}$, at node depths of 2,7 , and $20 \mathrm{~km}$. Velocity-depth profiles were made by connecting the nodes for every possible 1-D configuration while restricting the profile to avoid negative velocity gradients. Starting models were then made by individually hanging each 1-D velocity-depth profile from the model topography, yielding a consistent vertical gradient across the entire profile. Each starting model was then inverted with the same parameters used to derive the final model. The standard deviation of all the inversion results was then calculated to estimate model convergence among a range of initial models. Results of the Monte Carlo simulation show that each model converged to a model similar to our final model with an error of $\pm 100 \mathrm{~m} / \mathrm{s}$ in areas of dense ray coverage (Figure 4). Velocities are well constrained to $\sim 18 \mathrm{~km}$ depth and poorly constrained at the model edges below $4 \mathrm{~km}$ depth.

[20] To test the long-wavelength velocity structure resolution of our model, we performed a checkerboard test. This was done primarily to validate the observed structure beneath the extinct arcs at $\mathrm{km} 50$ and 110 along the profile. The checkerboard test was accomplished by calculating synthetic travel times through a perturbed velocity model while retaining the original survey geometry. We then added random noise of $\pm 50 \mathrm{~ms}$ to the synthetic travel times, inverted these synthetic data with an initial unperturbed model, and finally compared the recovery to the initial model. Our perturbed velocity model involved a checkerboard pattern of $40 \mathrm{~km} \times 5 \mathrm{~km}$ (horizontal $\times$ vertical sinusoid) using a velocity variation of $\pm 8 \%$ (Figure 7a). After five iterations, the inversion results show that the relatively highvelocity, long-wavelength structures to $10 \mathrm{~km}$ depth can be recovered but that lateral variations in velocity structure are poorly resolved beneath that depth (Figure 7b).

[21] To test the capability of our data and model parameters to resolve a fast velocity anomaly such as that observed beneath Barva volcano at $5 \mathrm{~km}$ depth, we used a similar procedure to the checkerboard test but embedded a single square high-velocity anomaly rather than a sinusoidal pattern. The anomaly embedded was a $10 \mathrm{~km} \times 2 \mathrm{~km}$ rectangle with an $8 \%$ velocity perturbation (Figure 8a). We then calculated synthetic travel times and inverted with the same parameters used to derive the final model. The result after five inversion iterations recovers the anomaly relatively well (Figure $8 \mathrm{~b}$ ). The boundaries of the anomaly are smeared, and the recovered anomaly has slightly lower velocity amplitude than the synthetic model. The velocity anomaly imaged beneath Barva in the final velocity model is thus likely spatially more compact with higher velocity amplitude in reality.

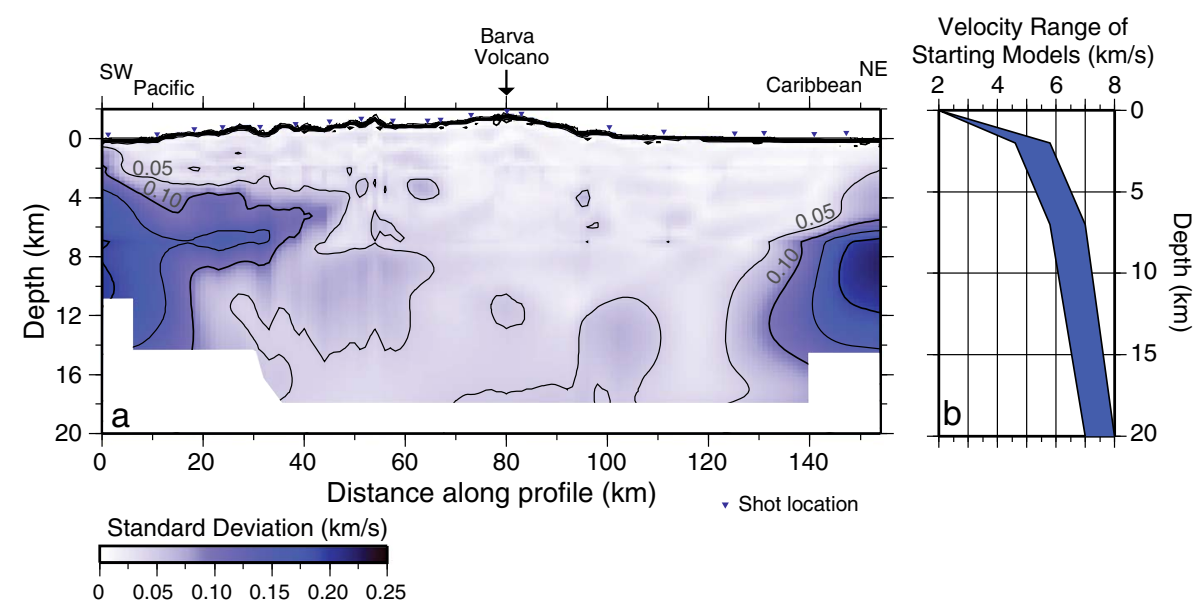

Figure 6. (a) Standard deviation result from Monte Carlo simulation of 343 starting models after five inversion iterations of travel-time tomography. Contour interval is $0.05 \mathrm{~km} / \mathrm{s}$ standard deviation. The estimated error for model space with dense ray coverage is $\pm 0.1 \mathrm{~km} / \mathrm{s}$. (b) Range of 1 -D velocity-depth profiles used as starting models. 

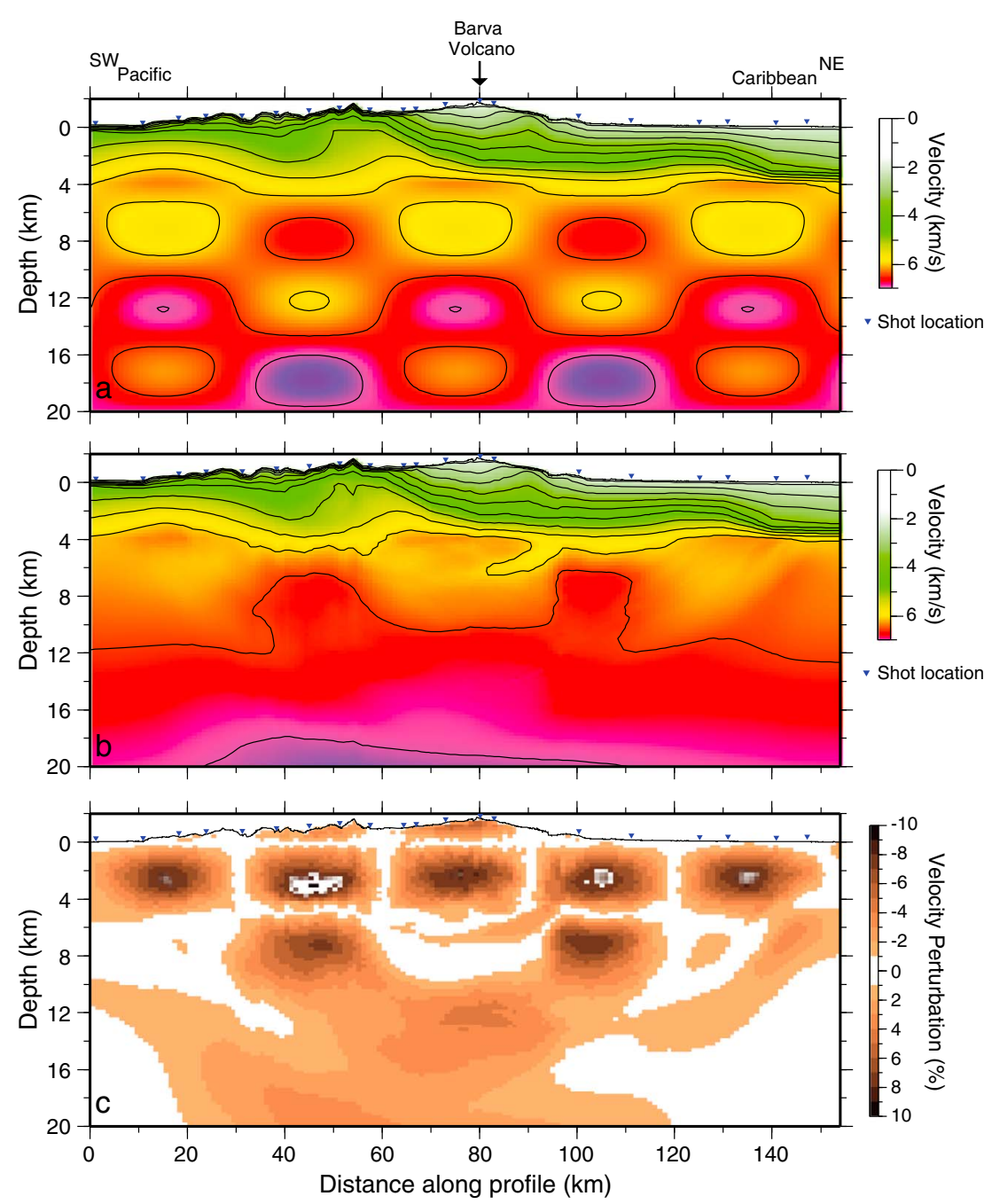

Figure 7. (a) Perturbed synthetic model used to test the long-wavelength resolution of the survey geometry. Model is perturbed with a $40 \mathrm{~km}$ horizontal wavelength by $5 \mathrm{~km}$ vertical wavelength sinusoid with $8 \%$ velocity variation. (b) Result of inversion using synthetic travel-time data calculated from Figure $7 \mathrm{a}$ and adding $\pm 50 \mathrm{~ms}$ of random noise to each travel-time calculation. (c) Recovered velocity model shown as percent velocity perturbation from the initial model.

\section{Discussion}

\subsection{Generation of Continental Crust at Arcs}

[22] Inferred mafic crustal compositions of the volcanic front in central Costa Rica from wide-angle seismic data coupled with geochemical observations of silicic melts at the surface [Vogel et al., 2004, 2006] suggest that arc crust in Costa Rica is actively differentiating toward continental compositions. The transition to mature continental material may yet occur by a variety of potential processes, including modification by accretion of the arc to other crustal material [Draut et al., 2009] and further differentiation that may lead to delaminating lower crustal material [Ducea and Saleeby, 1998]. Modification by accretion may be highly dependent on the composition of the accreting margin and the ability of magmatic mixing, assimilation, and further fractionation to occur. Delamination mechanisms, however, provide an in situ process for creating continental material within an island arc.

[23] Evolution of arc material to more silicic compositions via lower crustal delamination has been proposed to explain the andesite paradox [Ducea and Saleeby, 1998; Kay and Kay 1991, 1993; Herzberg et al., 1983; Behn and Kelemen, 2006; Kelemen, 1995]. In this case, ultramafic residuals eventually become dense enough to founder into the deeper mantle. This process has been evoked to explain the lack of a deep crustal "root" in the Sierra Nevada [Ducea and Saleeby, 1995], where the missing root assemblages are interpreted to have 


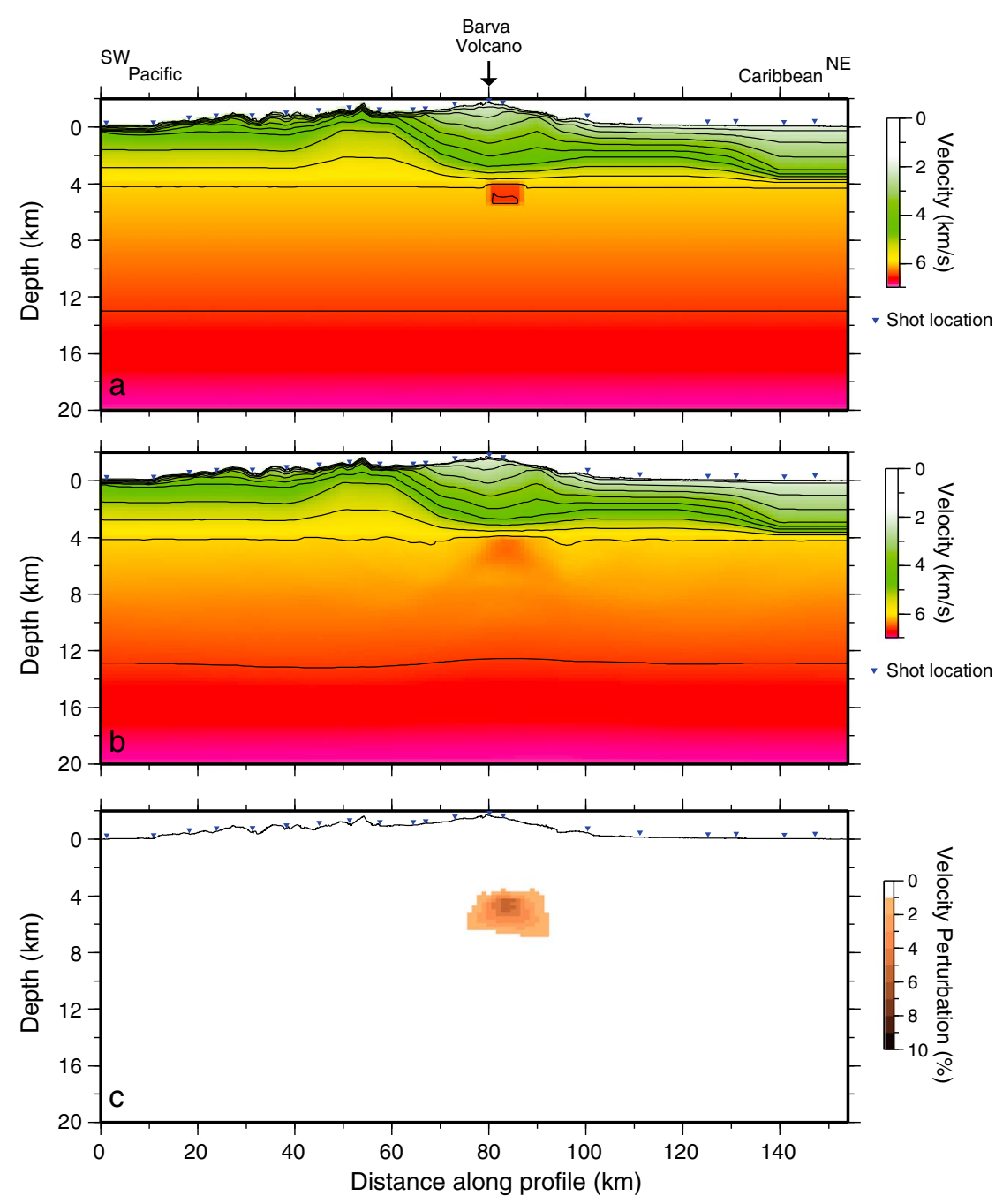

Figure 8. (a) Perturbed synthetic model used to test the resolving capability of the model geometry for a small highamplitude anomaly. A high-velocity box with a $2 \mathrm{~km}$ height, $10 \mathrm{~km}$ width, and $8 \%$ perturbation was embedded in a smoothed starting model beneath Barva volcano. (b) Result of inversion using synthetic travel-time data calculated from Figure $8 \mathrm{a}$ and adding $\pm 50 \mathrm{~ms}$ of random noise to each travel-time calculation. (c) Recovered velocity model shown as percent velocity perturbation from the initial model. The embedded anomaly is recovered, but the edges are smeared and the amplitude of velocity perturbation is reduced.

delaminated. While there is no evidence for this to have already occurred beneath our profile in central Costa Rica (i.e., no regional uplift or increased heat flow), progressive magmatic differentiation may lead to future foundering of the dense ultramafic residuals, cumulates, and garnet pyroxenites. The inferred average velocity of the lower crust in central Costa Rica likely does not reflect a large proportion of ultramafic material; however, the highly reflective CMTZ may indicate isolated regions of olivine cumulates or garnet-bearing phases. If sediment relamination [Hacker et al., 2011] is a major contributor to the growth of continental crust at the Costa Rican volcanic front (i.e., the velocity interpretations of a mafic lower crust are hindered by the presence of garnet, and the reflections are caused from diapiric relamination), then bulk continental crust may be significantly more felsic than predicted. In 2008, an onshore-offshore survey was conducted as an additional component of TICO-CAVA that will provide long enough offsets to further constrain lower crustal velocities and structure and possibly help resolve the relative contributions between magmatic and relamination processes.

\subsection{Comparison to Geophysical Studies of Other Active Arcs}

[24] There are striking differences and similarities between our results and those from intraoceanic 
arcs; in particular, we compare our results with geophysical studies of the Izu-Bonin and Aleutian arcs. The Aleutian arc is predominantly mafic and is characterized by a $35 \mathrm{~km}$-thick crust, three distinct compositional layers, a thick lower-crust, a welldefined Moho, and little extension [Calvert, 2011, and references therein]. The Izu-Bonin has variable crustal thickness $(10-35 \mathrm{~km})$, has a mafic bulk composition with heterogeneous areas of intermediatefelsic material, a highly reflective lower-crust with a 5-10 km-thick crust-mantle transition zone, and has seen relatively large amounts of extension [Calvert, 2011, and references therein]. Below we will briefly compare these arcs with our results.

[25] On average, velocities across the Costa Rican volcanic front are at the high-velocity extreme of bulk continental crust and slightly lower than modern island arc velocities (Figure 9). Seismic velocities less than $6.5 \mathrm{~km} / \mathrm{s}$ characterize crust above a depth of $13 \mathrm{~km}$ at the volcanic front, whereas crust in the Izu-Bonin and Aleutian arcs reach average velocities greater than this at depths of only $8-10 \mathrm{~km}$ [Calvert, 2011]. Velocities of $<6.5 \mathrm{~km} / \mathrm{s}$ are too low to be gabbroic and are commonly associated with tonalitic/ intermediate compositions [e.g., Calvert, 2011; Kawate and Arima, 1998; Suyehiro et al., 1996]. Despite the fact that velocities of mafic rock can be lowered by fractures and diagenesis in the

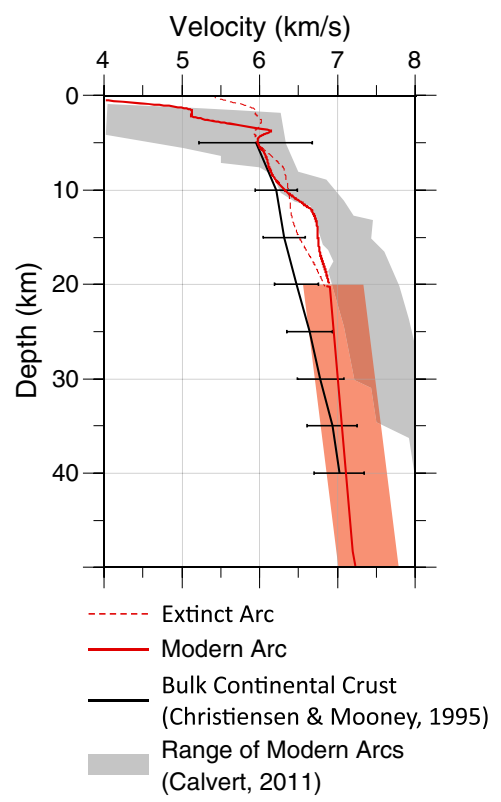

Figure 9. 1-D velocity-depth functions from our velocity model (red) compared with bulk continental crust [Christensen and Mooney, 1995] and the range of surveyed modern arcs [Calvert, 2011]. Shaded red region indicates the range of error from floating reflector statistics. shallow crust, the relatively low velocities found in central Costa Rica, particularly at depths greater than $8-10 \mathrm{~km} \quad(>0.2 \mathrm{GPa}$ confining pressure), suggest a larger proportion of felsic-intermediate compositions in the upper crust than found in the Aleutian and Izu-Bonin arcs. While only roughly constrained using average velocities obtained from reflected arrivals, mid-lower crustal velocities in central Costa Rica also appear on average to be lower than those found in other island arcs.

[26] The lower crust in central Costa Rica lacks the distinctly thick $(10-20 \mathrm{~km})$, high-velocity $(7.3-7.7 \mathrm{~km} / \mathrm{s})$ lower crust seen in the Aleutian arc [Holbrook et al, 1999; Schillington et al., 2004]. These high velocities have been interpreted by Schillington et al. [2004] as interlayered mafic residues and ultramafic cumulates along with abundant garnet-bearing assemblages. The estimated best-fit average velocities of the mid-lower crust based on floating reflectors beneath the active arc are between 6.8 and $7.1 \mathrm{~km} / \mathrm{s}$. The proportion of ultramafic and garnet-bearing mafic rocks is unclear from these roughly constrained velocities, but on average this velocity range suggests mafic compositions such as hornblendites and gabbro-norite-troctolites [Christensen and Mooney, 1995]. The lower crustal velocities likely include, at least in part, mafic velocities related to the CLIP upon which the volcanic arc in Costa Rica was built.

[27] The relatively low average velocities observed in the lower crust of the volcanic arc in central Costa Rica and the highly reflective crust-mantle transition zone likely represent complex interactions of crust and mantle during crustal growth as previously discussed. Sallarès et al. [2001] also suggest a transitional structure in northern Costa Rica interpreted as underplated magmas and serpentinized mantle. Similar transitional structure is also observed along the central Andean arc and the Izu-Bonin arc, where more evolved compositions are also inferred in the upper and mid-crust [ANCORP Working Group, 2003; Kodaira et al., 2007; Sato et al., 2009]. A transition zone in the central Andes is attributed to mechanical instability of the Moho from hydration of mantle rocks, magmatic intraplating and underplating, and partial melting [ANCORP Working Group, 2003]. Along the Izu-Bonin arc, a 5 to $10 \mathrm{~km}$-thick transition zone between $\sim 20$ and $30 \mathrm{~km}$ depth is interpreted, with velocities ranging between 7.2 and $7.6 \mathrm{~km} / \mathrm{s}$ [Kodaira et al., 2007; Tatsumi et al., 2008; Sato et al., 2009]. The Izu-Bonin CMTZ is comparatively well constrained from modeling of the velocity contrasts causing reflections [Sato et al., 2009] and interpreted to be a mixture of mafic restites and 
olivine cumulates that vary in proportion along the arc. The CMTZ in Costa Rica is likely similar in nature to the Izu-Bonin CMTZ with the possibility for a small component of relaminated sediments within the transition zone as previously discussed.

\subsection{Reflective Crust-Mantle Transition Zone}

[28] Data seen in shot gathers indicate a highly reflective lower crust, which has been modeled using floating reflectors (Figure 4). We interpret a roughly $10 \mathrm{~km}$-thick crust-mantle transition zone (CMTZ), with crustal thickness of $\sim 40 \pm 5 \mathrm{~km}$ below the active arc. This crustal thickness is in agreement with previous gravity and seismological studies [Lucke et al., 2010; MacKenzie et al., 2008; Sallarès et al., 1999]. The CMTZ may represent a mafic residual from differentiation of magmas [e.g., Kelemen et al., 2003], relamination of sediments [Hacker et al., 2011], and/or a small portion of ultramafic cumulates. We will briefly examine each of these possibilities in this section.

[29] The Costa Rican subduction zone is a nonaccreting margin [e.g., von Huene and Scholl, 1991] in which sediments and basement material from the slab may be subducting or accreting further inboard [Vannucchi et al., 2001]. This raises the possibility recently proposed by Hacker et al. [2011] that relamination of subducted sediments and eroded material from the upper plate is a mechanism for thickening arc crust and recycling continental material. Assuming a constant subduction rate of $\sim 87 \mathrm{~mm} / \mathrm{yr}$ [DeMets, 2001] since $\sim 65 \mathrm{Ma}$ [Meschede and Frisch, 1998] with a thickness of sediments subducted $\sim 0.5 \mathrm{~km}$ [Ivandic et al., 2008; van Avendonk et al., 2010] and density change of $\sim 300 \mathrm{~kg} / \mathrm{m}^{3}$ [Hacker et al., 2011], the total crosssectional area of subducted sediments over the life of the MAT can be estimated as $\sim 2500 \mathrm{~km}^{2}$. Given the approximate cross-sectional area of our profile $\left(\sim 4800 \mathrm{~km}^{2}\right)$ and the estimated area of preexisting CLIP across our profile ( 2000 to $\left.\sim 3000 \mathrm{~km}^{2}\right)$ from assuming a 12-20 km thickness found in studies of the adjacent Colombian Basin [Case et al., 1990], if all subducted sediment were relaminated beneath the arc, the expected volume would completely fill the available crustal space, leaving no room for new material from arc-related intrusions. This estimate is unreasonable given the voluminous magmatism observed across the volcanic arc in Costa Rica. Recent work has suggested that sediments from the Costa Rican subduction zone are being accreted under the coast, causing uplift but not reaching magma-generating depths [Sak et al., 2009]. Observed velocities and reflections in the mid-lower crust of our final velocity model do not preclude sediment relamination in producing crust in Costa Rica, especially if garnet-bearing metasediments exist. We recognize that some portion of sediments from the subducting slab may be relaminated and may help in producing impedance contrasts large enough to yield the reflections observed in the data, but the limited ray coverage from this data set make the proportions difficult to quantify.

[30] Another possible explanation for the reflective lower crust is that it represents mafic cumulates, intrusions, and restite - the result of magmatic differentiation. Kay and Kay [1982; 1993] propose that relatively felsic lavas can be produced in arcs by high-pressure fractionation of mantle-wedgederived magmas. If this process is responsible for the portion of felsic volcanism observed at the surface of the Central Volcanic Cordillera [Vogel et al., 2004], a large volume of mafic residual must reside in the middle and lower crust [White et al., 2006] beneath the Costa Rican volcanic front. In our final velocity model, mid- and lower-crustal velocities between 20 and $40 \mathrm{~km}$ depth average $7.0 \mathrm{~km} / \mathrm{s}$, and although there are large error bars of $\pm 0.5 \mathrm{~km} / \mathrm{s}$, this average velocity is consistent with a gabbroic composition [Christensen and Mooney, 1995]. Since this velocity range is too low to be predominantly ultramafic as predicted by velocities $>7.5 \mathrm{~km} / \mathrm{s}$ [Christensen and Mooney, 1995], we interpret this average velocity to represent mafic plutons and intrusions. Velocities within the CMTZ are not well constrained; thus, the exact velocity contrast causing these reflections is difficult to assess. A small portion of ultramafic cumulates within the mafic material would yield impedance contrasts large enough to generate a reflection.

\subsection{Aguacate and Sarapiquí Remnant Arcs}

[31] Neogene volcanism was focused along two remnant arcs: the Aguacate Arc, west of the Central Volcanic Cordillera [Alvarado et al., 2000] and the Sarapiquí Arc northeast of the Central Volcanic Cordillera [Gazel et al., 2005, 2009]. The volcanic center has since migrated from the Aguacate Arc northeastward to the Central Volcanic Cordillera in response to subduction of hotspot-thickened crust and subsequent slab shallowing [Marshall et al., 2003; Gazel et al., 2009, 2011]. Dense vegetation, ash flows, and other volcaniclastic sediments obscure the surface remnants of both extinct arcs; however, petrologic samples from 
outcrops and drill core reveal calc-alkaline volcanism [Alvarado et al., 2000; Alvarado and Gans, 2012; Marshall et al., 2003; Gazel et al., 2005]. Our profile traverses relatively close to the Palmares Caldera, a remnant of the extinct Aguacate Arc [Alvarado et al., 2000]. We interpret the long-wavelength, high-velocity feature on the western side of our profile to be remnant paleo-volcanism from the extinct Aguacate Arc and a similar feature on the eastern side of our profile to be the extinct Sarapiquí Arc (Figure 3a). A comparison between velocitydepth profiles beneath Barva volcano and the extinct Aguacate Arc show the extinct arc to have higher seismic velocities in the upper few kilometers and lower velocities in the mid-crust (Figure 9). Below $10 \mathrm{~km}$ depth, velocities in the modern arc are higher than those found in the Aguacate Arc. This may be the result of a higher degree of fractionation in the modern arc, where a relatively mafic residue is ponding in the mid-crust. Velocities of the modern arc above $10 \mathrm{~km}$ depth are lower than the Aguacate Arc but similar to those at the remnant Sarapiquí arc; this may be attributed to diagenesis and/or highporosity pyroclastic deposits such as tuffs and ignimbrites found near Barva [Denyer and Alvarado, 2007; Alvarado and Gans, 2012]. Higher velocities observed at the Agucate Arc within the upper $10 \mathrm{~km}$ may also be the result of more dioritic Neogene volcanism, as evidenced by a diorite intrusion that outcrops near our profile at Cedral Mountain [Lücke et al., 2010].

\subsection{Relict Magma Chamber}

[32] Barva is a dormant shield volcano that has produced a range of compositions from mafic basalts to more evolved andesites and trachytes, both common of volcanoes in Costa Rica [Pérez et al., 2006]. In our final velocity model, an isolated highvelocity anomaly $(\sim 6.2 \mathrm{~km} / \mathrm{s})$ is imaged beneath Barva volcano at $4 \mathrm{~km}$ depth (Figure $3 \mathrm{a}$ ). The resolution test indicates that a velocity anomaly beneath Barva is likely smaller in size and has even higher velocity amplitude than modeled. We interpret this anomaly as a relict magma chamber, in proximal agreement with depths of magma chambers predicted by petrological and geophysical studies of adjacent volcanoes [e.g., Alvarado et al, 2006; Benjamin et al., 2007; Martini et al., 2011; Lizarralde et al., 2010]. Hypocenters of recent seismic events associated with magma migration at Turrialba volcano are consistently placed at $4-6 \mathrm{~km}$ depth [Martini et al., 2011]. At neighboring Irazú, seismic swarms are common at depths shallower than $7 \mathrm{~km}$, with few occurring at depths up to $14 \mathrm{~km}$ [Barquero et al., 1995]. Density models from gravity data consistently place low-density heterogeneities related to Quaternary volcanism between 2 and $6 \mathrm{~km}$ depth [Lücke et al., 2010]. From petrographic and geobarometric analysis, Alvarado et al. [2006] conclude that two magma chambers exist beneath Irazú at depths $<5 \mathrm{~km}$ below the surface. A lowvelocity anomaly is predicted in the presence of an active magma chamber, so we propose that this high-velocity anomaly is produced by a relatively mafic cumulate residue of a previously active magma chamber.

\section{Summary}

[33] We modeled the seismic structure of the Central American Volcanic Arc in Costa Rica on a $154 \mathrm{~km}$-long, across-arc profile using a dense array of onshore receivers and explosive sources. Velocities in the uppermost crust are well constrained by travel-time tomography, and the mid-crust to lower crust is roughly constrained by ray trace modeling of reflections. From our velocity models, we conclude that $\mathrm{p}$-wave velocities across the Costa Rican volcanic front are at the high-velocity extreme of bulk continental crust and lower than modern intraoceanic arcs. Numerous reflections observed on shot gathers are interpreted as an extensive crust-mantle transition zone. This transition is likely a heterogeneous region consisting of relaminated sediment diapirs, cumulates, intrusions, and restite. Evolution of this crust to mature continental material may yet occur by continued fractionation and subsequent delamination. The thickened crust in this region may contribute to this evolution by acting as a density filter for mafic material thus enhancing the opportunity for differentiation and genesis of continental crust.

[34] Two areas of elevated upper crustal velocities are interpreted as remnants of the extinct Sarapiquí and Aguacate Arcs. A comparison between velocity-depth profiles beneath Barva volcano and the Cordillera de Aguacate shows that the extinct arc is faster in the upper few kilometers and slower in the mid-crust. The slower velocities in the upper $10 \mathrm{~km}$ at Barva volcano compared to those at the extinct arc are likely due to pyroclastic deposits and relatively felsic volcanism at the modern volcanic center. The higher velocities below $10 \mathrm{~km}$ depth may be the result of a higher degree of fractionation at the long-lived modern volcanic center. 


\section{Acknowledgments}

[35] Funding was provided by the NSF-MARGINS and ODP programs, under NSF grant OCE-0405654 and project $\mathrm{N}^{\circ} 113$ A4-408 from the University of Costa Rica. This survey was made possible by the hard work of numerous individuals and organizations. We thank the PASSCAL/IRIS instrument center for loaning the instruments; Cesar Villalta (Geoperforaciones) for drilling; Explotec, Inc., for explosives; the faculty, students, and staff of the Universidad de Costa Rica; FUNDEVI; the Instituto Costarricense de Electricidad; Marino Protti (OVSICORI); and the field efforts of Joel Seymour, Francisco Arias, Carlos Alonso Vargas, Pablo Ruiz, Daniel Murillo, Galen Kaip, Pnina Miller, Willie Zamora, and Greg Chavez. We would also like to thank two anonymous reviewers from whom this paper greatly benefited.

\section{References}

Abers, G. A., T. Plank, and B. R. Hacker (2003), The wet Nicaraguan slab, Geophys. Res. Lett., 30(2), doi:10.1029/ 2002 GL015649.

Albarède, F. (1998), The growth of continental crust. In Continents and Their Mantle Roots, Tectonophysics, edited by A. Vauchez and R.O. Meissner, vol. 296(1-2) pp. 1-14.

Alvarado, G. E., P. B. Gans (2012), Síntesis geocronológica del magmatismo, metamorfismo y metalogenia de Costa Rica, América Central, Rev. Geol. Amér. Central, 46, 7-122.

Alvarado, G. E., M. J. Carr, B. D. Turrin, C. C. Swisher, H.-U. Schmincke, and K.W. Hudnut (2006), Recent volcanic history of Irazú volcano, Costa Rica: Alternation and mixing of two magma batches, and pervasive mixing. In Volcanic Hazards in Central America: Geological Society of America Special Paper, edited by W. I. Rose, G. J. S. Bluth, M. J. Carr, J. Ewert, L. C. Patino, and J. Vallance, 412, 259-276, doi:10.1130/2006.2412(14).

Alvarado, G. E., W. Pérez, and C. Sigarán (2000), Vigilancia y peligro volcánico. In Geología de Costa Rica: Editorial Tecnológica de Costa Rica, edited by P. Denyer and S. Kussmaul, pp. 251-272.

ANCORP Working Group (2003), Seismic imaging of a convergent continental margin and plateau in the central Andes (Andead Continental Research Project 1996 (ANCORP'96)), J. Geophys. Res., 108(B7), 2328, doi:10.1029/2002JB001771.

Anderson, A. T. (1982), Parental basalts in subduction zones: Implications for continental evolution, J. Geophys. Res., 87, 7047-7060.

Barckhausen, U., C. R. Ranero, R. von Huene, S. C. Cande, and H. A. Roeser (2001), Revised tectonic boundaries in the Cocos Plate off Costa Rica: Implications for the segmentation of the convergent margin and for plate tectonic models, J. Geophys. Res. -Solid Earth, 106(B9), 19,207-19,220.

Barquero, R., P. Lesage, J. P. Metaxian, A. Creusot, and M. Fernández (1995), La crisis sísmica en el volán Irazú en 1991 (Costa Rica), Revista Geológica de América Central, 18, 5-18.

Baumgartner, P. O., K. Flores, A. N. Bandini, F. Girault, and D. Cruz (2008), Upper Triassic to Cretaceous radiolaria from Nicaragua and northern Costa Rica-The Mesquito Composite Oceanic Terrane, Ofioliti, 33, 1-19.

Behn, M. D., and P. B. Kelemen (2006), Stability of arc lower crust: Insights from the Talkeetna arc section, south central
Alaska, and the seismic structure of modern arcs, J. Geophs. Res., 111, B11207, doi:10.1029/2006JB004327.

Benjamin, E. R., T. Plank, J. A. Wade, K. A. Kelley, E. H. Haun, and G. E. Alvarado (2007), High water contents in basaltic magmas from Irazú Volcano, Costa Rica, J. Volcanol. Geotherm. Res., 168(1-4), 68-92.

Calvert, A. J. (2011), The seismic structure of island arc crust, in Arc-Continent Collision, edited by D. Brown and P. D. Ryan, Springer-Verlag, Berlin.

Calvert, A. J., S. L. Klemperer, N. Takahashi, and B. C. Kerr (2008), Three-dimensional crustal structure of the Mariana island arc from seismic tomography, J. Geophys. Res., 113, B01406, doi:10.1029/2007JB004939.

Carr, M. J. (1984), Symmetrical and segmented variation of physical and geochemical characteristics of the Central American volcanic front, J. Volcanol. Geotherm. Res., 20, 231-252.

Carr, M. J., M. D. Feigenson, and E. A. Bennett (1990), Incompatible element and isotopic evidence for tectonic control of source mixing and melt extraction along the Central American arc, Contribs. Mineral. Petrol., 105, 369-380.

Case, J. E., W. D. MacDonald, and P. J. Fox (1990), Caribbean crustal provinces; seismic and gravity evidence, In The Caribbean Region. The Geology of North America. H, edited by G. Dengo and J. E. Case. Boulder, Colorado. Geological Society of America, pp. 15-36.

Christensen, N., and W. Mooney (1995), Seismic velocity structure and composition of the continental crust: A global view, J. Geophys. Res., 100, 9761-9788.

DeMets, C. (2001), A new estimate for present-day CocosCaribbean plate motion: Implications for slip along the Central American volcanic arc, Geophys. Res. Lett., 28(21), 4043-4046.

Dengo, G. (1985), Mid America: Tectonic setting for the Pacific margin from southern Mexico to northwestern Columbia, in The Ocean Basins and Margins, edited by A.E. Nairn and F.G. Stechli, pp. 123-180, Plenum, New York.

Denyer, P., and G. E. Alvarado (2007), Mapa Geológico de Costa Rica, Editorial Francesa, San José, Costa Rica.

Draut, A., P. D. Clift, J. M. Amato, J. Blusztajn, and H. Schouten (2009), Arc-continent collision and the formation of continental crust: A new geochemical and isotopic record from the Ordovician Tyrone Igneous Complex, Ireland, J. Geol. Soc. London, 166, 484-500, doi:10.1144/0016-76492008-102.

Ducea, M., and J. Saleeby (1998), A case for delamination of the deep batholithic crust beneath the Sierra Nevada, California, International Geology Review, 40(1), 78-93.

Eiler, J. M., M. J. Carr, M. Reagan, and E. Stolper (2005), Oxygen isotope constraints on the sources of Central American arc lavas, Geochem. Geophys. Geosyst., 6, Q07007, doi:10.1029/2004GC000804.

Everson, E., W. S. Holbook, D. Lizarralde, H. Van Avendonk, and P. Denyer (2012), Seismic structure of the Central American subduction system through Costa Rica: Results from active-source seismic data, paper presented at the 2012 AGU Fall Meeting, AGU, San Francisco, California.

Gazel, E., G. E. Alvarado, J. Obando, and A. Alfaro (2005), Evolución magmática del arco de Sarapiquí, Costa Rica, Rev. Geol. Am. Cent., 32, 13-31.

Gazel, E., H. Hoernle, M. J. Carr, C. Herzberg, I. Saginor, P. van den Bogaard, F. Hauff, M. Feigenson, and C. Swisher III (2011), Plume-subduction interaction in southern Central America: Mantle upwelling and slab melting, Lithos, 121, 117-134, doi:10.1016/j.lithos.2010.10.008.

Gazel, E., M. J. Carr, K. Hoernle, M. D. Feigenson, D. Szymanski, F. Hauff, and P. van den Bogaard (2009), Galapagos-OIB signature in southern Central America: 
Mantle refertilization by arc-hot spot interaction, Geochem. Geophys. Geosyst., 10, Q02S11, doi:10.1029/2008GC002246.

Giunta, G., L. Beccaluva, and F. Siena (2006), Caribbean Plate margin evolution: Constraints and current problems, Geologica Acta, 4(1-2), 265-277.

Hacker, B. R., P. B. Kelemen, and M. D. Behn (2011), Differentiation of continental crust by relamination, Earth Planet. Sci. Lett., 307, 501-516, doi:10.1016/j.eps1.2011.05.024.

Hauff, F., K. Hoernle, P. van den Bogaard, G. Alvarado, and D. Garbe-Schönberg (2000), Age and geochemistry of basaltic complexes in western Costa Rica: Contributions to the geotectonic evolution of Central America, Geochem. Geophys. Geosyst., 1(5), 1009, doi:10.1029/1999GC000020.

Herzberg, C. T., W. S. Fyfe, and M. J. Carr (1983), Density constraints on the formation of the continental Moho and crust, Contrib. Minaral. Petrol., 84(1), 1-5.

Hoernle, K., et al. (2008), Arc-parallel flow in the mantle wedge beneath Costa Rica and Nicaragua, Nature, 451, 1094-1097, doi:10.1038/nature06550.

Holbrook, W. S., D. Lizarralde, S. McGeary, N. Bangs, and J. Diebold (1999), Structure and composition of the Aleutian island arc and implications for continental crustal growth, Geology, 27, 31-34.

Hughes, G. R., and G. A. Mahood (2008), Tectonic controls on the nature of large silicic calderas in volcanic arcs, Geology, 36(8), 627-630.

Husen, S., R. Quintero, E. Kissling, and B. Hacker (2003), Subduction-zone structure and magmatic processes beneath Costa Rica constrained by local earthquake tomography and petrological modeling, Geophys. J. Int., 155(1), 11-32.

Ivandic, M., I. Grevemeyer, A. Berhorst, E. R. Flueh, and K. McIntosh (2008), Impact of bending related faulting on the seismic properties of the incoming oceanic plate offshore of Nicaragua, J. Geophys. Res., 113, B05410, doi:10.1029/ 2007JB005291.

Kawate, S., and M. Arima (1998), Petrogenesis of the Tanzawa plutonic complex, central Japan: Exposed felsic middle crust of the Izu-Bonin-Mariana arc, Island Arc, 7, 342-358.

Kay, R. W., and S. M. Kay (1993), Delamination and delamination magmatism, Tectonophysics, 219, 177-189.

Kay, R. W., and S. M. Kay (1991), Creation and destruction of lower continental crust, Geol. Rundsch., 80, 259-278.

Kay, R. W., and S. M. Kay (1986), Petrology and geochemistry of the lower continental crust: An overview, edited by J. B. Dawson, D. A. Carswell, J. Hall, and K. H. Wedepohl, The nature of the lower continental crust, Geol. Soc. London Special Publication, 24, 147-159.

Kay, S. M., R. W. Kay, and G. P. Citron (1982), Tectonic controls on the tholeiitic and calc-alkaline magmatism in the Aleutian arc, J. Geophs. Res., 87, 4051-4072.

Kelemen, P. B., G. M. Yogodzinski, and D. W. Scholl (2003), Along-strike variation in lavas of the Aleutian island arc: Implications for the genesis of high $\mathrm{Mg \#}$ andesite and the continental crust. In Inside the Subduction Factory, $A G U$ Monograph, edited by J. Eiler, 138, pp. 223-276.

Kelemen, P. B. (1995), Genesis of high Mg\# andesites and the continental crust, Contrib. Mineral. Petrol.,120, 1-19.

Kodaira, S., S. Takeshi, N. Takahashi, A. Ito, Y. Tamura, Y. Tatsumi, and Y. Kaneda (2007), Seismological evidence for variable growth of crust along the Izu intraoceanic arc, J. Geophys. Res., 112, B05104, doi:10.1029/2006JB004593.

Korenaga, J., W. S. Holbrook, G. M. Kent, P. B. Kelemen, R. S. Detrick, H.-C. Larsen, J. R. Hopper, and T. Dahl-Jensen (2000), Crustal structure of the southeast Greenland margin from joint refraction and reflection seismic tomography, J. Geophys. Res., 105, 21,591-21,614.
Linkimer, L., S. L. Beck, S. Y. Schwartz, G. Zandt, and L. Vadim (2009), Nature of crustal terranes and the Moho in northern Costa Rica from receiver function analysis, Geochem. Geophys. Geosyst., 11(1), Q01S10, doi:10.1029/2009GC002795.

Lizzaralde, D., W. S. Holbrook, H. J. Van Avendonk, M. Mora Fernandez, G. E. Alvarado, and S. H. Harder (2010), Crustal Structure along the Active Costa Rican Volcanic Arc, Abstract T13A-2176 Presented at 2010 Fall Meeting, AGU, San Francisco, Calif.

Lucke, O. H., H.-J. Götze, and G. E. Alvarado (2010), A constrained 3D density model of the upper crust from gravity data interpretation for central Costa Rica, Int. J. Geophys., 860902, doi:10.1155/2010/860902.

MacKenzie, L., G. A. Abers, K. M. Fischer, E. M. Syracuse, J. M. Protti, V. Gonzlez, and W. Strauch (2008), Crustal structure along the southern Central American volcanic front, Geochem. Geophys. Geosyst., 9, Q08S09, doi:10.1029/ 2008GC001991.

Marshall, J. S., B. D. Idleman, T. W. Gardner, and D.M. Fisher (2003), Landscape evolution within a retreating volcanic arc, Costa Rica, Central America, Geology, 31(5), 419-422.

Martini, F., F. Tassi, O. Vaselli, R. Del Potro, M. Martinez, R. Van del Laat, and E. Fernandez (2011), Geophysical, geochemical and geodetical signals of reawakening at Turrialba volcano (Costa Rica) after almost 150 years of quiescence, J. Volcan Geotherm. Res., 198, 416-432, doi:10.1016/j.jvolgeores.2010.09.021.

McIntosh, K. (2000), Large aperture seismic imaging at a convergent margin: Techniques and results from the Costa Rica seismogenic zone, Marine geophysical researches, 21, 451, doi:10.1023/A:1026597927732.

McIntosh, K.D., Y. Nakamura, E. Flueh, G. Leandro, and TICO-SECT participants (1995), TICOSECT: Experiments to evaluate the crustal structure of the Costa Rica convergent margin, Eos Trans. AGU, 76, 551.

Meschede, M., and W. Frisch (1998), A plate tectonic model for the Mesozoic and Early Cenozoic history of the Caribbean plate, Tectonophysics, 296, 269-291.

Patino, L. C., M. J. Carr, and M. D. Feigenson (2000), Local and regional variations in Central American arc lavas controlled by variations in subducted sediment input, Contrib. Mineral. Petrol., 138, 265-283, doi:10.1007/s004100050562.

Pérez, W., G. E. Alvarado, and P. B. Gans (2006), The 322 ka Tiribí Tuff: Statigraphy, geochronology and mechanisms of deposition of the largest and most recent ignimbrite in the Valle Central, Costa Rica, Bull. Volcanol., 69, 25-40, doi:10.1007/s00445-006-0053-x.

Protti, M., F. Gundel, and K. McNally (1994), The geometry of the Wadati-Benioff zone under southern Central-America and its tectonic significance: Results from a high-resolution local seismography network, Phys. Earth Planet. Inter., 84, 271-287, doi:10.1016/0031-9201(94)90046-9.

Ranero, C. R., J. P. Morgan, K. D. McIntosh, and C. Reichert (2001), Flexural faulting and mantle serpentinization at the Middle America Trench, Eos Trans. AGU, 82, T22D-T22D04.

Rogers, R. D., P. Mann, and P. A. Emmet (2007), Tectonic terranes of the Chortis block based on integration of regional aeromagnetic and geologic data, Spec. Pap. Geol. Soc. Am., 428, 65-88, doi:10.1130/2007.2428(04).

Rudnick, R. L. (1995), Making continental crust, Nature, 378, 571-577.

Rudnick, R. L., and D. M. Fountain, (1995), Nature and composition of the continental crust: A lower crustal perspective, Reviews of Geophys., 33, 267-309.

Rudnick, R. L., and S. Gao (2003), The composition of the continental crust. In Treatise on Geochemistry, edited by 
H. D. Holland and K. K. Turekian, Oxford: Elsevier, 3, pp. 1-64.

Rüpke, L. H., J. P. Morgan, M. Hort, and J. A. D. Connolly (2002), Are the regional variations in Central American arc lavas due to differing basaltic versus peridotitic slab sources of fluids?, Geology, 30, 1035-1038.

Sak, P. B., D. M. Fisher, T. W. Gardner, J. S. Marshall, and P. C. LaFemina (2009), Rough crust subduction, forearc kinematics, and Quaternary uplift rates, Costa Rican segment of the Middle American Trench, GSA Bulletin, 121, 992-1012.

Sallarés, V., J. J. Dañobeitia, E. Flueh, and G. Leandro (1999), Seismic velocity structure across the Middle America land bridge in northern Costa Rica, J. Geodyn., 27, 327-344, doi:10.1016/S0264-3707(98)00007-6.

Sallarés, V., J. J. Dañobeitia, and E. Flueh (2000), Seismic tomography with local earthquakes in Costa Rica, Tectonophysics, 329, 61-78, doi:10.1016/S0040-195(00)00188-8.

Sallarés, V., J. J. Dañobeitia, and E. Flueh (2001), Lithospheric structure of the Costa Rican Isthmus: Effects of subduction zone magmatism on an oceanic plateau, J. Geophys. Res., 106(B1), 621-643, doi:10.1029/2000JB900245.

Sato, T., S. Kodaira, N. Takahashi, Y. Tatsumi, and Y. Kaneda (2009), Amplitude modeling of the seismic reflectors in the crust-mantle transition layer beneath the volcanic front along the northern Izu-Bonin island arc, Geochem. Geophys. Geosyst., 10, Q02X04, doi:10.1029/2008GC001990.

Schillington, D. J., H. J. A. Van Avendonk, W. S. Holbook, P. B. Kelemen, and M. J. Hornbach (2004), Composition and structure of the central Aleutian island arc from arc-parallel wide-angle seismic data, Geochem. Geophys. Geosys., 5(10), Q10006, doi:10.1029/2004GC000715.

Sinton, C. W., R. A. Duncan, M. Storey, J. Lewis, and J. J. Estrada (1998), An oceanic flood basalt province within the Caribbean Plate, Earth Planet. Sci. Lett., 155, 221-235, doi:10.1016/S0012-821X(97)00214-8.

Smith, R. A. (1999), Macroscopic P-wave anisotropy in the Haast Schist, New Zealand: implications for errors in wideangle seismic studies of metamorphic terranes, Dep. of Geol. and Geophys., Univ. of Wyoming, Laramie, Wyoming, United States.

Smithson, S. B., R. A. Johnson, and Y. K. Wong (1981), Mean crustal velocity: A critical parameter for interpreting crustal structure and crustal growth, Earth Planet. Sci. Lett., 53, 323-332.

Suyehiro, K., N. Takahashi, Y. Yokoi, R. Hino, M. Shinohara, T. Kanazawa, N. Hirata, H. Tokuyam, and A. Taira (1996), Continental crust, crustal underplating and low-Q upper mantle beneath an oceanic island arc, Science, 272, 390-392, doi:10.1126/science.272.5260.390.

Takahashi, N., S. Kodaira, and Y. Tatsumi (2008), Structure and growth of the Izu-Bonin-Mariana arc crust: 1. Seismic constraint on crust and mantle structure of the Mariana arc and back-arc system, J. Geophys. Res., 113, B01104.
Tarantola, A. (1987), Inverse Problem Theory, Elsevier Sci, New York, 613 pp.

Tatsumi, Y., H. Shukuno, K. Tani, and N. Takahashi (2008), Structure and growth of the Izu-Bonin-Mariana arc crust: 2 . Role of crust-mantle transformation and the transparent Moho in arc crust evolution, J. Geophys. Res., 113, B02203.

Taylor, S., and S. McLennan (1981), The composition and evolution of the continental crust: Rare earth element evidence from sedimentary rocks, Royal Society of London Philosophical Trans., 301, 381-399.

Taylor, S., and S. McLennan (1985), The Continental Crust: Its Composition and Evolution, Blackwell, Malden, Mass.

Van Avendonk, H. J. A., W. S. Holbrook, D. Lizarralde, M. M. Mora, S. Harder, A. D. Bullock, G. E. Alvarado, and C. J. Ramírez (2010), Seismic evidence for fluids in fault zones on top of the subducting Cocos plate beneath Costa Rica, Geophys. J. Int., 181, 997-1016, doi:10.1111/j.1365246X.2010.04552.x.

Vannucchi, P., D. W. Scholl, M. Meschede, and K. McDougallReid (2001), Tectonic erosion and consequent collapse of the Pacific margin of Costa Rica: Combined implications from ODP Leg 170, seismic offshore data, and regional geology of the Nicoya Peninsula, Tectonics, 20, 649-668.

Vogel, T. A., L. C. Patino, G. E. Alvarado, and P. B. Gans (2004), Silicic ignimbrites within the Costa Rican volcanic front: Evidence for the formation of continental crust, Earth Planet. Sci. Lett., 226, 149-159, doi:10.1016/j.epsl.2004.07.013.

Vogel, T. A., L. C. Patino, J. K. Eaton, J. W. Valley, W. I. Rose, G. E. Alvarado, and E. L. Viray (2006), Origin of silicic magmas along the Central American volcanic front: Genetic relationship to mafic melts, J. Volcanol. Geotherm. Res., 156, 217-228, doi:10.1016/j.jvolgeores.2006.03.002.

von Huene, R., and D. W. Scholl (1991), Observations at convergent margins concerning sediment subduction, subduction erosion, and the growth of continental crust, Rev. Geophys., 29, 279-316.

von Huene, R., et al. (1995), Morphotectonics of the Pacific convergent margin of Costa Rica, in Geologic and Tectonic Development of the Caribbean Plate Boundary in Southern Central America, ed. P. Mann, Spec. Pap. Geol. Soc. Am., 295, 291-307.

von Huene, R., C. R. Ranero, W. Weinrebe, and K. Hinz (2000), Quaternary convergent margin tectonics of Costa Rica, segmentation of the Cocos Plate, and Central American volcanism, Tectonics, 19(2), 314-334, doi:10.1029/1999TC001143.

White, S. M., J. A. Crisp, and F. J. Spera (2006), Long-term volumetric eruption rates and magma budgets, Geochem. Geophys. Geosyst., 7, Q03010, doi:10.1029/2005GC001002.

Zelt, C.A., and D.A. Forsyth (1994), Modeling wide-angle seismic data for crustal structure: Southeastern Grenville province, J. Geophys. Res., 99, 11,687-11,704.

Zelt, C. A., and R. B. Smith (1992), Seismic traveltime inversion for 2-D crustal velocity structure, Geophys. J. Int., 108(1), $16-34$. 